\title{
Incongruências classificatórias: uma análise dos discursos sobre as propostas da CID11 em relação às experiências trans*
}

\author{
Hugo Alejandro Cano-Prais** \\ Alexandre Costa-Val*** \\ Érica Renata de Souza******
}

\begin{abstract}
Resumo
Investigamos, neste artigo, os discursos relacionados à classificação das experiências trans presentes em um sítio criado pela Organização Mundial de Saúde na ocasião da construção da $11^{\mathrm{a}}$ Classificação Estatística Internacional de Doenças e Problemas Relacionados com a Saúde (CID11). Trata-se de um estudo qualitativo em que analisamos as falas de 16 participantes, estabelecendo quatro eixos de discussão, que, finalmente, se convergem em torno da concepção da "Incongruência de Gênero" como uma "perturbação físico-moral". Nesse percurso, o ato social de classificar assim como as possibilidades de cuidado das pessoas trans fora do marco patológico são problematizados.
\end{abstract}

Palauras-chave: Transexualidade, Classificações, Cuidados em Saúde, Ciência.

\footnotetext{
* Recebido em 08 de fevereiro de 2019, aceito em 30 de abril de 2020.

** Psiquiatra, Professor do Departamento de Medicina de Família, Saúde Mental e Coletiva (DEMSC) da Escola de Medicina da Universidade Federal de Ouro Preto (UFOP), Ouro Preto, MG, Brasil. Integrante do Núcleo de Investigação das Subjetividades Contemporâneas (NISC)-UFOP e do Grupo de Estudos Feminismo e Relações de Gênero (FAFICH/UFMG). Doutorando do Programa de Pós-Graduação em Saúde Coletiva do Instituto de Medicina Social Hesio Cordeiro da Universidade do Estado do Rio de Janeiro (PPGSC-IMSHC-UERJ). hugoprais@ufop.edu.br / http://orcid.org/0000-0001-8432-1650

*** Psiquiatra, Professor do Departamento de Medicina de Família, Saúde Mental e Coletiva (DEMSC) da Escola de Medicina da Universidade Federal de Ouro Preto (UFOP) e integrante do Núcleo de Investigação das Subjetividades Contemporâneas (NISC)-UFOP, Ouro Preto, MG, Brasil. alecostaval@yahoo.com.br / http://orcid.org/0000-0003-1334$\underline{6054}$

**** Cientista Social, Professora do Departamento de Antropologia e Arqueologia da Faculdade de Filosofia e Ciências Humanas (FAFICH), Universidade Federal de Minas Gerais (UFMG), coordenadora do Grupo de Estudos Feminismo e Relações de Gênero (FAFICH/UFMG) e vinculada ao Núcleo de Direitos Humanos e Cidadania LGBT (NUH), FAFICH/UFMG), Belo Horizonte, MG, Brasil. Pesquisadora do Grupo de Estudos Interdisciplinares em Ciência e Tecnologia (GEICT) do Instituto de Geociências da UNICAMP. erica0407@gmail.com / http://orcid.org/0000-0003-2195$\underline{8237}$
} 


\section{Introdução}

A sexualidade se constituiu, ao longo da história, como elemento fundamental das vicissitudes no Ocidente. Entendida como encarnação da "verdade" de cada um de nós, seu estudo pode revelar alguns dos processos sociais mais significativos das sociedades modernas, em especial aqueles que culminaram na concepção do indivíduo e de suas formas de subjetivação (Russo, 2004). Tais processos são engendrados por jogos de poder que desvelam, finalmente, que a eficiência dos mecanismos de controle dos corpos se deve não exatamente à repressão, mas à incitação à produção de discursos, práticas e saberes que assujeitam indivíduos e produzem subjetividades (Foucault,1999a; 2009).

Nessa dinâmica, é notável a hegemonia do discurso médico-psiquiátrico, que, particularmente a partir do século XIX, tem se esforçado para definir comportamentos sexuais normais, disfuncionais e desviantes. Ainda que qualquer classificação seja um ato essencialmente humano um ato em que as coisas e as experiências do mundo sensível ganham inteligibilidade a partir de decisões arbitrárias (Durkheim, Mauss, 1981) —sua operacionalização no campo das sexualidades contribuiu para naturalizar categorias dicotômicas que restringem formas de ser e estar no mundo.

Em se tratando de modos de vida que não se adequam à lógica binária e heteronormativa estabelecida pelas "normas de gênero" (Butler, 2003), essa questão se torna patente. Do pecado ao desvio moral, das parafilias às lesões cerebrais (Leite Jr., 2011), o campo composto por uma heterogeneidade de vivências relativas ao sexual é marcado por processos de disputas, negociações, sujeições e resistências que tentam, a todo tempo, torná-lo socialmente inteligível e controlável. Nesse contexto, as experiências trans ${ }^{1}$ são paradigmáticas.

Circunscritas por contornos que variam de acordo com o contexto histórico e social, elas evidenciam a forma como práticas e discursos regulam como os indivíduos se relacionam com eles mesmos e com os outros (Borba, 2016). Harry Benjamin (1966) foi um dos pioneiros a descrever o "fenômeno transexual" no meio médico, contribuindo para consolidar a narrativa hegemônica de que a pessoa transexual é aquela que, desde a infância, demanda viver e ser aceita enquanto uma pessoa do gênero oposto àquele heterodesignado. O quadro viria acompanhado de desconforto persistente com o próprio sexo atribuído, ojeriza aos órgãos genitais e tendência à depressão e ao suicídio.

Atualmente, critérios de manuais diagnósticos - como os da Classificação Estatística Internacional de Doenças e Problemas Relacionados com a Saúde (CID), organizada pela Organização Mundial de Saúde (OMS) e adotada no Brasil — fazem parte do cotidiano dos serviços assistenciais dedicados a pessoas trans. Esse discurso classificatório sedimenta um regime de verdade que integra o "dispositivo da transexualidade" (Bento, 2008). Trata-se de uma rede composta por "(...) discursos, instituições, organizações arquitetônicas, decisões regulamentares, leis, medidas administrativas, enunciados científicos, proposições filosóficas, morais, filantrópicas" (Foucault, 2011:244) que, em última instância, promove a essencialização de uma identidade transexual imaginária com fins de regulação dos corpos e do espaço social.

$\mathrm{O}$ não reconhecimento de formas de existência que escapam ao enquadramento do diagnóstico funciona como uma violência simbólica, que exclui a pessoa da própria condição de humano. Patologizar é, nesse sentido, conferir inteligibilidade a partir de uma norma que invisibiliza as práticas e toda a humanidade que a excede (Butler, 2004). Os direitos jurídicos, políticos e sociais são, assim, negados, precarizando todos aqueles que ficam à margem dessa rede.

No Brasil, o Sistema Único de Saúde (SUS) incluiu, em 2008, o processo transexualizador ${ }^{2}$ em sua cartela de procedimentos, estabelecendo um protocolo rígido, norteado pela concepção da

\footnotetext{
1 Neste artigo, usaremos o termo "experiências trans" - ou simplesmente o adjetivo trans - na tentativa de nos distanciar do marco patológico do discurso médico-psiquiátrico que, a partir de nomeações tais como transexualismo e travestismo, define modos hegemônicos de se vivenciar as transexualidades.

2 O processo transexualizador pode ser entendido como "um conjunto de estratégias de atenção à saúde implicadas no processo de transformação dos caracteres sexuais pelos quais passam indivíduos transexuais em determinado momento de suas vidas. Não se trata, portanto, do estabelecimento de diretrizes para a atenção integral no sentido estrito, mas daquelas ações necessárias à garantia do direito à saúde circunscritas à passagem para a vivência social no gênero em desacordo com o sexo de nascimento" (Lionço, 2009:44).
} 
transexualidade como um transtorno mental. Essa perspectiva, defendida pelos manuais médicos de diagnóstico, parte do princípio de que essas experiências são enfermidades, cujos tratamentos abarcam não só intervenções psicoterápicas, mas também intervenções no corpo para adequá-lo à identidade de gênero com a qual a pessoa se identifica. A sequência de procedimentos préestabelecidos engloba acompanhamento psicológico compulsório, comprovações de que o sujeito convive bem socialmente com o gênero com o qual se identifica, ratificação da condição através de laudos médico-psiquiátricos, os tratamentos hormonais, procedimentos cirúrgicos e trâmites burocráticos para mudança do prenome e do sexo nos documentos (Arán; Murta; Lionço, 2009). Em 2013, uma nova portaria passou a regular esse processo ${ }^{3}$, que, apesar de ter sido redefinido e ampliado, se manteve sustentado pelo marco patológico (Souza; Braz, 2016).Ou seja, o direito à autonomia $e$ às intervenções no corpo continuam só sendo possíveis se a pessoa aceitar a ser tratada como "doente" (Ávila, 2014).

$\mathrm{Na}$ contramão dessa concepção, movimentos sociais - como, por exemplo, o Stop Trans Pathologization - têm contestado, há mais de dez anos, a hegemonia do discurso biomédico sobre as experiências trans e a suposta psicopatologia dessa condição. Uma questão recorrente nessa luta é como despatologizar, garantindo, ao mesmo tempo, o acesso dessa população ao cuidado integral em saúde (Almeida; Murta, 2013; Prado, 2018). Tal indagação não apresenta solução préestabelecida e exige discussões que devem ser localizadas de acordo com a realidade de cada local (Bento, 2018).

No cenário nacional, pesquisadores e ativistas se engajam nessa causa, abrindo possibilidades para a construção de novos formatos assistenciais às pessoas trans (Almeida; Murta, 2013; Bento; Pelúcio, 2012; Lionço, 2009). Alguns serviços já têm colocado em ato formas de cuidado que subvertem classificações e hierarquias hegemônicas, respeitando, assim, a singularidade de cada um (Prado, 2018:50).Nesse processo, é notável o protagonismo dos conselhos de psicologia, que, diferentemente das instituições médicas, tensionam perspectivas diversas e desestabilizam o domínio médico-psiquiátrico nesse campo (Pacheco; Rasera; Prado; Teixeira, 2017). Entretanto, como o diagnóstico médico ainda continua sendo o meio legal que regula o acesso à procedimentos específicos, é preciso manter viva a problematização das categorias nosológicas para avançarmos no debate em relação à despatologização.

No intuito de fomentar essa discussão, propomos, neste artigo, investigar o "dispositivo da transexualidade" a partir da análise das falas presentes em um sítio criado pela OMS na ocasião da construção da CID 11. Esse espaço virtual foi estabelecido para sustentar um debate público, aberto aos interessados, a respeito de todas as categorias diagnósticas propostas pelo manual, incluindo não só as doenças orgânicas e os quadros psiquiátricos, mas também as codificações de contato com os serviços de saúde e os diversos procedimentos que porventura possam ser realizados. Nessa investigação, nos detivemos aos conteúdos relativos às transexualidades, que, conforme a proposta da CID 11, passará a ser nomeada como "Incongruência de Gênero"4, em uma categoria dissociada dos transtornos mentais. Dada a diversidade dos participantes e suas diferentes perspectivas, entendemos que esse material se constitui como objeto privilegiado para uma análise que nos dê indicações de como ocorrem as disputas e negociações na regulação dos corpos e das experiências trans na atualidade. Afinal, a reiteração classificatória faz parte da patologização das transexualidades, a qual, por sua vez, "é uma questão de poder" (Prado, 2018:53). No Brasil, essa discussão se torna especialmente importante tendo em vista que serviços e profissionais da saúde se utilizam, com maior ou menor grau de criticidade, das codificações da CID em suas práticas cotidianas.

\footnotetext{
3 A partir dessa época, as pessoas travestis e os homens trans foram autorizados a usufruir dos serviços oferecidos.

4 Segundo a CID 11, a "Incongruência de Gênero" é caracterizada por marcante e persistente incongruência entre o gênero experienciado por um indivíduo e o seu sexo designado. Geralmente, as pessoas com esse quadro apresentam aversão ou desconforto com caracteres sexuais primários e secundários do sexo designado e forte desejo de ter caracteres sexuais primários e secundários do gênero experienciado. O estabelecimento da congruência pode incluir tratamentos hormonais, cirurgias ou outros cuidados em saúde que permitam que o corpo se alinhe ao gênero experienciado, de acordo com o desejo do indivíduo.
} 


\section{Percurso metodológico}

Trata-se de um estudo qualitativo cujo objeto foram as falas extraídas do sítio ${ }^{5}$ criado pela OMS com o objetivo de fomentar o debate sobre categorias diagnósticas propostas pela CID 11. Essa etapa (fase beta) de construção do manual foi precedida de outra (fase alfa) em que 24 grupos, compostos por especialistas, revisaram categorias e critérios diagnósticos da CID 10, suprimindo, alterando e acrescentando novos elementos. O site continha o resultado de tais intervenções e esteve aberto entre 2012 e 2017 para que quaisquer interessados, mediante o cadastro prévio, tecessem comentários e sugestões. A expectativa era que a análise dessas considerações pudesse contribuir para maior estabilidade do manual.

Dado o objetivo de nossa investigação, nos detivemos nas falas registradas entre 20/12/2012 a 31/01/2016 que estiveram relacionadas ao grupo diagnóstico nomeado, na fase alfa, como "Condições relacionadas à saúde sexual", mais especificamente naquelas relativas à categoria geral "Incongruência de Gênero" e à subcategoria "Incongruência de Gênero na adolescência ou na vida adulta" (figura 1). Para acessar o sítio, um dos pesquisadores fez o cadastro, participando, na maior parte do tempo, como observador.

Figura 1: Capítulo 17, intitulado como "Condições relacionadas à saúde sexual", e suas subdivisões, conforme proposta da CID11

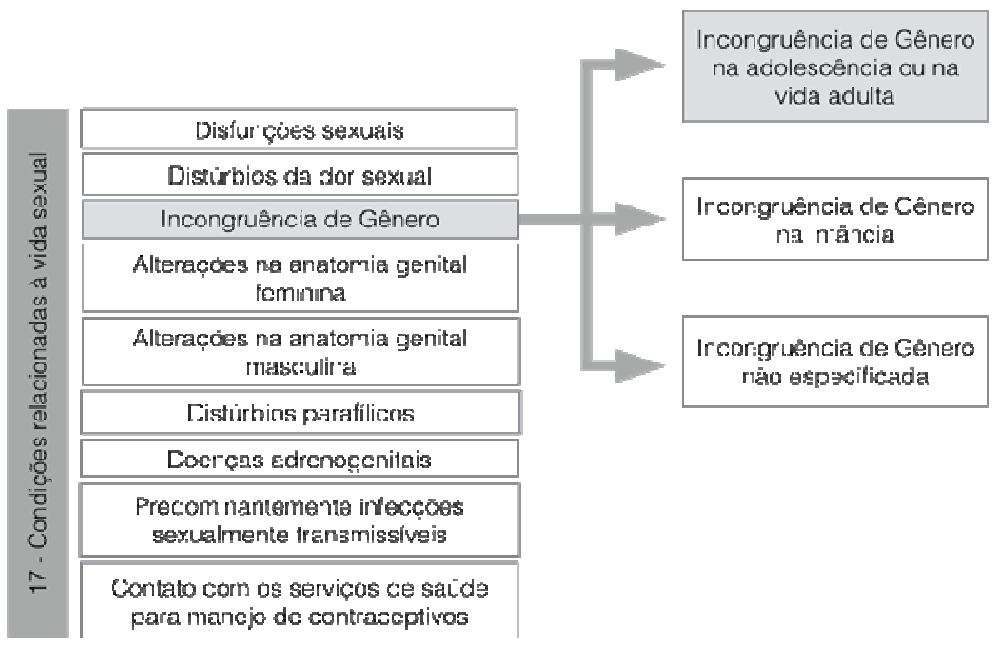

Fonte: Confeccionada pelos autores.

Dezesseis pessoas estiveram envolvidas nessas discussões. Para preservar o anonimato, cada participante foi definido pela sigla de algum estado brasileiro. Todos foram identificados de acordo com a nacionalidade e, quando possível, com a forma como se apresentavam (tabela 1). Analisamos um total de 64 falas, sendo que 12 delas se referiam à nomeação "Incongruência de gênero" e 52, à definição da condição em si. Destas últimas, duas foram do pesquisador principal desta investigação.

\footnotetext{
5 O sítio da fase beta da CID 11 (ICD-11 BETA DRAFT) pode ser encontrado em: http://apps.who.int/classifications/icd11/browse/l-m/en\#/http\%3a\%2f\%2fid.who.int\%2ficd\%2fentity\%2f90875286

${ }^{6}$ Devido às especificidades dessa temática na infância, optamos por não incluir a categoria "Incongruência de Gênero na infância" neste estudo.
} 


\begin{tabular}{|c|c|c|c|c|c|c|}
\hline \multicolumn{3}{|c|}{ Participantes } & \multicolumn{2}{|c|}{ Incongruência de Gênero } & \multicolumn{2}{|c|}{$\begin{array}{c}\text { Incongruência de Gênero } \\
\text { na adolescência ou na } \\
\text { vida adulta }\end{array}$} \\
\hline Identificação & $\begin{array}{c}\text { Forma de } \\
\text { apresentação }\end{array}$ & Nacionalidade & $\begin{array}{c}\text { Comentários } \\
\text { ao título }\end{array}$ & $\begin{array}{l}\text { Comentários } \\
\text { à definição }\end{array}$ & $\begin{array}{c}\text { Comentários } \\
\text { ao título }\end{array}$ & $\begin{array}{c}\text { Comentários } \\
\text { à definição }\end{array}$ \\
\hline $\mathrm{AM}$ & $\begin{array}{c}\text { vinculado à } \\
\text { universidade }\end{array}$ & Alemanha & 1 & 6 & 4 & 12 \\
\hline MG & $\begin{array}{c}\text { vinculado à } \\
\text { universidade }\end{array}$ & Brasil & 0 & 0 & 0 & 3 \\
\hline $\mathrm{RS}$ & - & Rússia & 1 & 2 & 0 & 0 \\
\hline SE & $\begin{array}{c}\text { feminista } \\
\text { radical }\end{array}$ & $\begin{array}{l}\text { Estados } \\
\text { Unidos }\end{array}$ & 1 & 0 & 1 & 0 \\
\hline $\mathrm{BA}$ & $\begin{array}{c}\text { vinculado à } \\
\text { universidade }\end{array}$ & Paquistão & 1 & 0 & 0 & 0 \\
\hline GO & - & Nova Zelândia & 1 & 2 & 1 & 4 \\
\hline SP & - & $\begin{array}{l}\text { Estados } \\
\text { Unidos } \\
\end{array}$ & 0 & 3 & 0 & 4 \\
\hline PI & $\begin{array}{l}\text { mulher trans } \\
\text { vinculada à } \\
\text { universidade }\end{array}$ & Reino Unido & 0 & 0 & 0 & 4 \\
\hline $\mathrm{AL}$ & $\begin{array}{c}\text { vinculado à } \\
\text { universidade }\end{array}$ & Venezuela & 0 & 0 & 0 & 2 \\
\hline DF & - & Canadá & 0 & 0 & 0 & 1 \\
\hline $\mathrm{RR}$ & mulher trans & Alemanha & 0 & 0 & 0 & 5 \\
\hline MA & - & Austrália & 0 & 0 & 0 & 1 \\
\hline $\mathrm{RO}$ & estudante & Reino Unido & 0 & 0 & 0 & 1 \\
\hline PB & $\begin{array}{c}\text { vinculado à } \\
\text { universidade }\end{array}$ & $\begin{array}{l}\text { Estados } \\
\text { Unidos } \\
\end{array}$ & 0 & 0 & 0 & 1 \\
\hline ES & - & $\begin{array}{l}\text { Estados } \\
\text { Unidos } \\
\end{array}$ & 0 & 0 & 0 & 1 \\
\hline SC & - & $\begin{array}{l}\text { Estados } \\
\text { Unidos }\end{array}$ & 0 & 0 & 1 & 0 \\
\hline
\end{tabular}

A análise teve como referência a proposta de Foucault (2008) de que o discurso, para além dos signos que remetem a conteúdos ou a representações, se constituem com "práticas que formam sistematicamente os objetos de que falam" (2008:55). Seguindo essa indicação, nos esforçamos para descrevê-los, localizando quem e como os pronunciou, assim como o contexto sócio-histórico em que eles estavam inscritos. Tanto quanto possível, tentamos evidenciar as regras que regeram as condições de exercício da função enunciativa (Foucault, 1999b), mantendo, ao mesmo tempo, as incoerências, contradições e descompassos entre as diversas falas, que traduzimos, livremente, do inglês para o português.

Para operacionalizarmos nosso trabalho, separamos quatro eixos de análise e discussão (figura 2) que foram se destacando a partir do tensionamento entre as percepções e interpretações de cada um dos pesquisadores, após a leitura exaustiva do material. Mantivemos essa divisão na apresentação e discussão dos resultados, sustentados pelo diálogo crítico entre nosso grupo de trabalho e a literatura referente ao campo da saúde, das ciências humanas e das ciências sociais. 
Figura 2: Eixos de análise e discussão
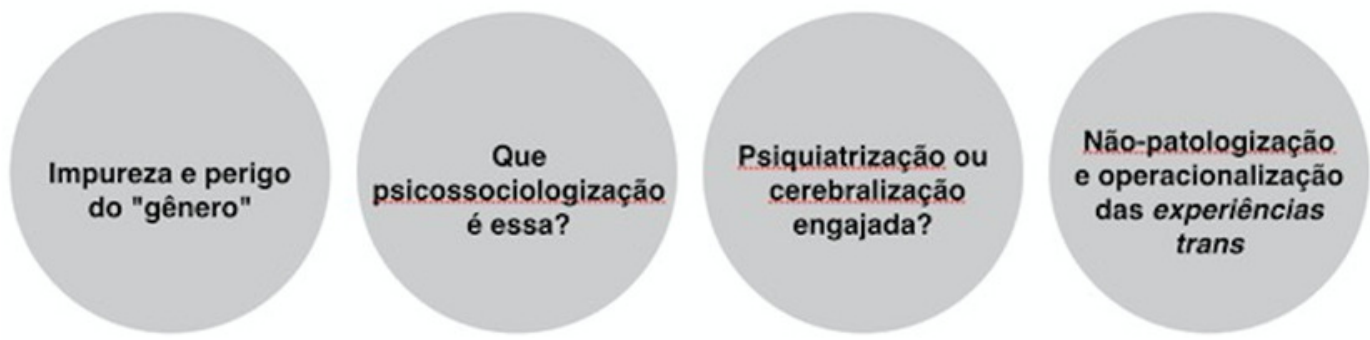

Fonte: Confeccionada pelos autores.

\section{Resultados e discussão}

Impureza e perigo do "gênero"

As experiências trans já foram nomeadas de diversas formas nos manuais que determinam os critérios diagnósticos dos quadros que compõem a nosologia médica. No caso específico do Manual de Diagnóstico e Estatística dos Transtornos Mentais (DSM) ${ }^{7}$,sustentado pela Associação Americana de Psiquiatria, houve certa gradação: o que era definido por "Transexualismo" se tornou "Transtorno de Identidade de Gênero", que, por sua vez, mais recentemente passou a ser reconhecido como "Disforia de Gênero". Já na CID, a transição proposta é mais direta: do "Transexualismo", subcategoria de um subgrupo de transtornos psiquiátricos conhecido como "Transtornos da Identidade Sexual", à "Incongruência de Gênero", subcategoria de um grupo não pertencente aos quadros psiquiátricos nomeado como "Condições relacionadas à Saúde Sexual" (figura 3).

Figura 3: Linha histórica da $\mathrm{CID}^{8}$

\begin{tabular}{|l|}
\hline \multicolumn{1}{|c|}{ CID 7 (1955) } \\
\hline $\begin{array}{l}\text { V. Transtornos Mentais, Psiconeuróticos e de } \\
\text { personalidade }\end{array}$ \\
\hline $\begin{array}{l}\text { Transtornos de caráter, de comportamento e } \\
\text { inteligência }\end{array}$ \\
\hline 320 Personalidade patológica \\
\hline 302.0 Personalidade esquizóide \\
\hline 320.1 Personalidade paranóide \\
\hline 320.2 Personalidade ciclotímica \\
\hline 302.3 Personalidade inadequada \\
\hline 302.4 Personalidade antisocial \\
\hline 302.5 Personalidade associal \\
\hline $\begin{array}{l}\text { 302.6 Desvio sexual: Exibicionismo; Feitichismo; } \\
\text { Homossexualismo; Sexualidade patológica; Sadismo; } \\
\text { Desvio Sexual }\end{array}$ \\
\hline 302.7 Personalidade patológica não especificada \\
\hline
\end{tabular}

\begin{tabular}{|l|}
\hline \multicolumn{1}{|c|}{ CID 8 (1965) } \\
\hline $\begin{array}{l}\text { V. Transtornos Mentais, Psiconeuróticos e de } \\
\text { personalidade }\end{array}$ \\
\hline $\begin{array}{l}\text { Transtornos neuróticos, transtornos da } \\
\text { personalidade e outros transtornos mentais não } \\
\text { psicóticos }\end{array}$ \\
\hline 302 Desvios sexuais \\
\hline 302.0 Homossexualismo \\
\hline 302.1 Fetichismo \\
\hline 302.2 Pedofilia \\
\hline 302.3 Transvestismo \\
\hline 302.4 Exibicionismo \\
\hline 302.5 Voyerismo \\
\hline 302.6 Sadismo \\
\hline 302.7 Masoquismo \\
\hline 302.8 Outros \\
\hline 302.9 Não especificados \\
\hline
\end{tabular}

\footnotetext{
7 Vale lembrar que o DSM, embora seja largamente utilizado na literatura biomédica, não é a referência para notificações psiquiátricas no Brasil. Adotá-lo como "verdade universal" implica em desconsiderar as particularidades de nosso sistema de saúde cuja construção, diferentemente do modelo estadunidense, conta com a participação dos movimentos sociais $e$ do Estado (Bento, 2018).

8 Os quadros psiquiátricos começaram a fazer parte da CID a partir de sua sexta edição em 1948. Dada sua semelhança com a CID 7, nesta figura partimos desta versão para evidenciar que, até 1955, as transexualidades eram englobadas dentro do "desvio sexual" nomeado como "homossexualismo". Na CID 8, o "transvestismo" foi incorporado e, a partir da CID 9, as transexualidades ganharam uma nomeação própria.
} 


\begin{tabular}{|l|}
\hline \multicolumn{1}{|c|}{ CID 9 (1979) } \\
\hline V. Transtornos Mentais \\
\hline $\begin{array}{l}\text { Transtornos neuróticos, transtornos da } \\
\text { personalidade e outros transtornos mentais não } \\
\text { psicóticos }\end{array}$ \\
\hline 302 Desvios e transtornos sexuais \\
\hline 302.0 Homossexualismo \\
\hline 302.1 Bestialidade \\
\hline 302.2 Pedofilia \\
\hline 302.3 Transvestismo \\
\hline 302.4 Exibicionismo \\
\hline 302.5 Trans-sexualismo \\
\hline 302.6 Transtorno da identidade psicossexual \\
\hline 302.7 Frigidez e impotência \\
\hline 302.8 Outros \\
\hline 302.9 Não especificados \\
\hline
\end{tabular}

\begin{tabular}{|l|}
\hline \multicolumn{1}{|c|}{ CID 10 (1989) } \\
\hline V. Transtornos Mentais e comportamentais \\
\hline $\begin{array}{l}\text { Transtornos de personalidade e do } \\
\text { comportamento no adulto }\end{array}$ \\
\hline F64 Transtorno da identidade sexual \\
\hline F64.0 Transexualismo \\
\hline F64.1 Travestismo ambivalente \\
\hline $\begin{array}{l}\text { F64.2 Transtorno de identidade sexual na } \\
\text { infância }\end{array}$ \\
\hline F64.8 Outros transtornos da identidade sexual \\
\hline $\begin{array}{l}\text { F64.9 Transtorno não especificado da } \\
\text { identidade sexual }\end{array}$ \\
\hline
\end{tabular}

Fonte: Confeccionada pelos autores.

Essas novas classificações revelam a tendência de se incluir a palavra "gênero" nas nomeações diagnósticas atuais. Esse termo, no entanto, foi questionado por diversos participantes: "Esta seção seria melhor intitulada como 'Disforia Sexual Biológica', pois a questão subjacente para os transexuais é uma desconexão entre sua verdade biológica e uma ficção mental sobre sua biologia." (GO); "[a ideia de] (...) papéis de gênero é o que frequentemente causa problemas de saúde mental e disforia de gênero (...)" (DF).

Tais ponderações parecem se sustentar na própria história da concepção do conceito de gênero. Na década de 1950, John Money, sexologista neozelandês, se apropriou desse constructo para resolver o impasse relativo ao diagnóstico e à terapêutica dos corpos intersexuais, ou seja, corpos cujas anatomias não se encaixavam dentro da lógica binária macho-fêmea. Ao apoiar um determinismo de influências sociais e ambientais, o foco da abordagem para conciliar o sexo e o gênero passou a se centrar na matriz da anatomia corporal. Esse tipo de conduta, pouco tempo depois, foi consagrado por Harry Benjamin como forma de "tratamento" das pessoas transexuais (Cyrino, 2013). A exigência de uma coerência entre sexo e gênero, numa perspectiva essencialista, tornou-se a base da matriz heterossexual no pensamento ocidental (Butler, 2003).

Ao que tudo indica, é nesse sentido que as falas dos participantes ressaltaram que "gênero", por se tratar de um conceito atrelado à ideia de uma construção psicossocial sem um suporte (biológico) fixo, é algo instável e problemático. É como se a criação dessa categoria movediça, ao abrir um leque de possibilidades de intervenções corporais, produzisse por si só o adoecimento psíquico conhecido como "transexualidade". Seguindo a perspectiva de Mary Douglas (1991), o gênero foi entendido por muitos como um conceito "impuro" $e$ "perigoso" que deveria ser eliminado em prol da "saúde" e da ordem social:

Além disso, como a questão paralela relativa à construção social do 'gênero' é prejudicial à saúde mental de todas as pessoas - homens e mulheres - é melhor que a questão subjacente da disforia corporal do paciente seja o foco e não o 'gênero', que é algo que deveria ser abolido para o bem de todos (GO).

Chamou-nos atenção a proximidade de discursos como esse com aqueles que circulam no Brasil sob os auspícios da expressão "ideologia de gênero", utilizada por segmentos políticos de direita ligados a setores conservadores das igrejas católica e neopentecostais. Essa manobra segue a lógica de um sistema de acusação que representa "uma estratégia mais ou menos consciente de manipular poder e organizar emoções, delimitando fronteiras" (Velho, 2008:59). Tal ataque tem sido dirigido a qualquer um que defenda direitos de mulheres ou da população LGBT, expressando uma visão de mundo, não de ordem explicativa, mas de ordem moral (Miskolci, 2018). 
Em nossa investigação, o combate à ameaça do "gênero" pôde ser verificado em diversas propostas de "purificação" dessa categoria. Todas elas recaíram na ideia de que existe uma essência natural da sexualidade dos seres humanos. Duarte (1999) esclarece que a concepção de "natureza humana" foi sedimentada pelo fisicalismo, movimento ideológico surgido entre os séculos XVII e XVIII decorrente da separação radical entre corpo e alma. Sobre essa base, a corporalidade passou a ser concebida como um substrato material dotado de lógica própria capaz de esgotar a explicação da "essência" humana. Há, nessa direção, diferentes vertentes que sustentam esse tipo de racionalidade universalista na civilização ocidental contemporânea.

Entre elas, destaca-se aquela "iluminada" pelo discurso biomédico, que, centrado nos aspectos anatômicos e fisiológicos do corpo humano, passou a reger regimes de verdade da Ciência moderna. O radicalismo desse tipo de proposição tornou o corpo, em seu sentido mais orgânico, centro de toda e qualquer experiência humana, culminando, finalmente, em um reducionismo fisicalista (Duarte, 2004). Isso fica evidente, por exemplo, na primeira fala apresentada, cuja sugestão é a de que a ênfase das experiências trans incida sobre o corpo - e não sobre o gênero - a partir da insígnia "Disforia Sexual Biológica". No mesmo sentido, outra participante ressaltou: "Não se trata de 'gênero', mas de partes do corpo 'não ajustadas' que se desenvolveram em discordância com o sexo (em um sentido mais amplo). 'Transexual' descreve essa variação relacionada ao corpo. (...)" (RR)

Há, aí, uma clara referência aos aspectos corporais em detrimento de estereótipos de gênero. Caberia, nesse contexto, nos perguntarmos: qual biologia carregaria a "verdade" do sexo? Seriam os genitais? Os hormônios? Os cromossomos?

Segundo Duarte (1994), esse tipo de determinismo biomédico, ao longo do século XX, sofreu alguns ataques que assumiram duas formas distintas: o "psicologicismo" e o "sociologismo". A primeira sustenta a existência de uma realidade interna específica regida por monções, nomeadas como psicológicas, psíquicas ou inconscientes, que se destacam da corporalidade estrita. Já a segunda defende que a experiência humana decorre exclusivamente do condicionamento promovido pelo campo social. Essas duas correntes parecem se reencontrar, mais contemporaneamente, na ideia de "determinantes psicossociais", que, embora promova alguma vacilação no reducionismo fisicalista, acaba assumindo um tom igualmente essencialista sustentado pela concepção de "natureza humana". Além disso, a "virada somática" que marca nossos tempos contribui para que todas essas perspectivas se misturem, assumindo diferentes matizes marcadas pela proeminência do corpo (Russo, 2017).

Esse aspecto foi evidente na fala de uma participante:

Eu argumento que ninguém sabe o que o gênero realmente é, $e$ as pessoas estão apenas se enganando se pensam o contrário. A única razão da maioria das pessoas não estarem familiarizadas com a visão do feminismo radical sobre gênero é devido ao fato dos ativistas transgêneros terem conseguido silenciar o pensamento das mulheres através de bullying e táticas de intimidação. (...) Feministas radicais são críticas em relação ao gênero em si. Nós não somos reformistas de gênero - somos abolicionistas de gênero. Sem os papéis de gênero socialmente construídos que formam a base do patriarcado, todas as pessoas estariam livres para se vestir, se comportar e amar os outros da maneira que quisessem, não importando o tipo de corpo que tivessem. (...) Feministas radicais acreditam também que a mulher tem o direito de definir seus limites e decidirem quem é permitido em seus espaços. (SE)

Tal crítica é baseada na ideia de que o conceito de gênero foi apropriado de forma a reproduzir as relações de poder entre homens e mulheres. O gênero se torna, assim, uma maneira de indicar as construções sociais dos ideais dos "papéis" ${ }^{10}$ próprios aos homens e às mulheres,

\footnotetext{
9 Ressaltamos que o autor não assume uma posição crítica em relação a todas as construções do conhecimento que aconteceram nos campos da psicologia e da sociologia, mas àquelas ancoradas em uma perspectiva essencializada, naturalizada e, consequentemente, patologizante das relações dos seres humanos com o seu psiquismo ou entorno social.

${ }^{10}$ Colocaremos sempre o conceito de "papel" entre aspas devido a sua limitação conceitual e analítica, pois carrega um sentido de fixidez. Essa ideia tem sido paulatinamente substituída pela noção de "performatividade" (Butler, 2002, 2003, 2004), que não ignora a materialidade dos corpos, mas se afasta de qualquer ranço essencialista.
} 
constituindo-se, finalmente, como categoria social rígida que impõe certa hierarquia aos corpos sexuados (de Santana, 2016). Embora essa fala pareça indicar uma defesa da circulação dos corpos, independentemente de qualquer identidade subjetiva socialmente produzida, ela acaba por reificar alguma separação a partir da biologia. Afinal, quais seriam "as mulheres" a que essa participante se refere? Essa questão parece se esclarecer em outro discurso: "A base da opressão feminina é procedente da biologia. A existência de pessoas intersexuais não nega isso uma vez que é também baseada na biologia do corpo e não na identidade abstrata adotada por qualquer indivíduo em particular" (RO).

Essa defesa, apesar de apresentar um apelo político-social, nos lança, mais uma vez, na reafirmação do essencialismo dos corpos sexuados apoiada no fisicalismo. Um fisicalismo que, embora se sustente em aspectos iminentemente orgânicos, parece adquirir uma perspectiva um pouco menos reducionista ao contemplar a interação dos corpos com o meio social (Russo, 2017). Nas análises seguintes, verificaremos como os elementos físicos e morais vão imiscuindo-se uns aos outros de forma a esboçar eixos temáticos mais ou menos impuros, nunca homogêneos e sempre imperfeitos.

\section{Que "psicossociologização" é essa?}

Conforme assinalamos, Harry Benjamin foi um dos pioneiros a descrever aquilo que ele chamou de "fenômeno transexual", contribuindo de forma decisiva para que essas experiências se tornassem alvo do discurso médico-psiquiátrico. Esse médico sustentava que existiam diferentes tipos de "sexos", que variavam do genético ao social. Embora ele acreditasse na existência de um "sexo psicológico", atribuindo-lhe, inclusive, certa autonomia a ponto de poder ser discordante dos demais, alegava que essa expressão decorria diretamente de influências hormonais. Sua tese, de orientação claramente fisicalista, defendia que essa discordância poderia assumir diferentes estágios: pseudotravesti; travesti fetichista; travesti verdadeiro; transexual não cirúrgico; transexual de intensidade moderada; transexual de alta intensidade. Benjamin era incisivo quanto à importância de se diferenciar essas categorias tendo em vista que, em sua perspectiva, apenas aquelas pessoas que se encontravam nos três últimos estágios se beneficiariam das intervenções cirúrgicas. As transexualidades, a partir daí, começaram a ganhar contornos um pouco mais nítidos, destacandose das homossexualidades, das travestilidades e das intersexualidades (Santos, 2011). Essa tendência acabou sendo adotada pelos manuais psiquiátricos que, desde a década de 1980, passaram a classificar cada uma dessas entidades separadas umas das outras. Na prática, como veremos, essa questão ainda causa impasse.

Pouco tempo depois, a leitura psicossocial de Money, ao enfatizar a importância da sociabilização e do aprendizado no estabelecimento dos "papéis" e identidades de gêneros, assim como da orientação sexual, ampliou, por um lado, o campo de investigação sobre o tema. Por outro, no entanto, ela acabou sendo usada muito mais para justificar intervenções de caráter comportamental de forma a produzir uma coerência entre sexo, gênero e orientação sexual com base no binarismo heteronormativo do que para ampliar as possibilidades de acolhimento das diversidades sexuais (Santos, 2011).

Nessa mesma via, outro exponente na história do "dispositivo da transexualidade" - o psicanalista Robert Stoller - estabeleceu seus estudos a partir do trabalho com diversos meninos cujos pais os consideravam "afeminados". Seu objetivo era entender como e quais processos de sociabilização poderiam acarretar uma identidade de gênero discordante do sexo biológico. Apoiado em teorias freudianas, na época já reapropriadas de formas questionáveis nos Estados Unidos da América, o psicanalista defendeu que essa desarmonia era oriunda de uma relação disfuncional com os pais, especialmente com a mãe. Para ele, uma dinâmica familiar marcada por uma mãe dominadora e por um pai ausente criaria ambiente propício para o desenvolvimento de um "transexual verdadeiro". Seguindo essa tese, Stoller recomendava intervenções precoces do terapeuta no sentido de criar um "complexo de Édipo terapeuticamente induzido" que permitisse a criança se desidentificar da mãe e se identificar com elementos atribuídos ao gênero masculino. $\mathrm{O}$ psicanalista, assim, diferentemente de Benjamin e de Money, se posicionava contra as cirurgias de 
redesignação sexual, apostando exclusivamente nas intervenções psicoterápicas (Santos, 2011; Borba, 2016).

Todas essas elaborações, que incluem desde a ideia de um "sexo psicológico" (ainda que biologicamente determinado), passando pela vertente do aprendizado a partir das relações interpessoais na infância ou pela ideia normativa de um Édipo funcional, apontam, de alguma maneira, para elementos que não coincidem exatamente com a visceralidade orgânica dos corpos. Tais perspectivas, no entanto, embora pareçam dar um outro colorido em teorias fisicalistas mais radicais - provocando, algumas vezes, certa vacilação - carregam um tom igualmente essencialista, determinista e moralizante. Seguindo essa pista, a partir de falas que analisamos, estabelecemos como eixo de discussão a "psicossociologização" ${ }^{11}$. De forma geral, os discursos aqui descritos fazem referência aos aspectos psíquicos e sociais envolvidos em certas concepções das transexualidades que remetem às elaborações de Benjamin, Money e Stoller.

A insistência em se manter as experiências trans ligadas à saúde mental foi frequente. É o caso, por exemplo, de um participante que questionou a proposta de se colocar a "Incongruência de Gênero" em categoria separada dos quadros psíquicos ("Condições relacionadas à Saúde Sexual"), justificando que a ausência de um substrato cerebral a aproxima de outros sofrimentos mentais consagrados. Ele ainda completou que:

(...) essas definições são aplicáveis a todas as pessoas com 'Incongruência de Gênero', incluindo Travestis Fetichistas (e esta definição foi agora suprimida de forma misteriosa da CID). Para muitos, talvez para a maioria dos homens que se transicionam tardiamente para se tornarem transexuais, o Travestismo Fetichista seja o primeiro estágio (SP).

Em sua fala, ele contestou a proposta de suprimir a subcategoria "Travestismo Fetichista" que na CID 10 faz parte do subgrupo "Transtornos da Preferência Sexual" — ressaltando que esse quadro se constitui como um dos estágios das transexualidades. É curioso que, apesar do entendimento de que essas manifestações se constituem como uma entidade psíquica, o participante faz uma referência clara ao modelo da "história natural" das doenças orgânicas, localizando o "Travestismo Fetichista" como uma espécie de "estado pré-mórbido" da transexualidade. Essa ideia de um continuum, fundada por Benjamin, parece corroborar certos ideais de "tratamento" que ora se encontram, ora se distanciam:

Transexuais masculinos e femininos são pessoas que têm uma percepção mental de sua biologia que está em desacordo com a sua realidade biológica. Para eles, a disforia é tão significativa e intratável que a única solução é a cirurgia cosmética para fazer com que seu corpo pareça menos com a sua verdade biológica e mais com a sua ficção mental. (...) As pessoas transgêneros masculinas e femininas geralmente não têm problemas significativos com o corpo, a não ser um desejo fetichista de se apresentar usando maneirismos e comportamentos que a sociedade habitualmente espera de pessoas do sexo oposto. Elas querem usar banheiros, vestiários e outras instalações reservadas para o sexo oposto. Elas são, geralmente, heterossexuais. Na minha opinião, o fetichismo deveria ser tratado e não encorajado (GO).

Outra participante, embora concordasse com essa diferenciação entre "transexuais" $e$ "transgêneros" - diferenciação comum entre os estadunidenses que não se sedimentou no Brasil - ressaltou que nenhuma dessas condições implica em determinada orientação sexual. Cumpre lembrar que até a década de 1970, apesar dos esforços de Benjamin para estabelecer um diagnóstico diferencial, o "transexualismo" e o "homossexualismo" recebiam abordagens médicopsicológicas semelhantes. Foi apenas em 1973, quando as homossexualidades deixaram de ser consideradas quadros patológicos pela Associação Americana de Psiquiatria (ver na figura 3 como essa tendência foi incorporada pela CID), que as transexualidades foram agrupadas em uma

\footnotetext{
${ }^{11}$ O termo "psicossociologização" não desconsidera a importância de elaborações e atuações da sociologia e da psicologia que contribuíram (e contribuem) para ruptura da lógica fisicalista e classificatória, mas pretende problematizar discursos que, embora possam ser referidos a esses campos, mantêm-se ancorados em perspectivas anacrônicas que, como as de Benjamin, Money e Stoller, pouco contribuíram para desestabilizar as normas que regem os corpos e as subjetividades no Ocidente.
} 
categoria própria (Dunker; Kyrillos Neto, 2010). No entanto, no senso comum, assim como em certos estudos e práticas, ainda se observa uma associação entre ambas as condições.

A mesma participante, além de esclarecer a diferença entre gênero e orientação sexual, foi incisiva ao refutar a necessidade de tratamento de "transgêneros" sem o consentimento das pessoas assim classificadas:

\begin{abstract}
Se uma pessoa transgênero busca voluntariamente por tratamento, de maneira geral o comportamento não deve ser nem incentivado nem desencorajado. Ao invés disso, a psicoterapia requer decisões individuais do terapeuta sobre como cada indivíduo deve ser melhor ajudado (AM).
\end{abstract}

Apesar da pontuação acima, o protagonista da fala anterior insistiu: "As duas classes mais relevantes para a maioria dos casos são: 1) transexualidade: homens gays altamente afeminados; 2) transgênero: homens heterossexuais com um fetiche narcísico por parecer e se comportar de maneira estereotipadamente feminina" (GO).

Embora não fique claro qual seria a forma de "tratamento" que ele defende para o caso dos transgêneros, é inevitável remeter sua ideia de "homens gays altamente afeminados" à proposta de abordagem cunhada por Stoller. Há, nesse sentido, tendência de se adotar um procedimento pedagógico de correção em detrimento de uma intervenção que requer a autorização $e$ o engajamento do sujeito em um processo criativo de construção de um modo autêntico de vida, independentemente de qualquer normatização. Nada muito distante daquilo que, contemporaneamente, tem sido nomeado como "cura gay" (Dunker; Kyrillos Neto, 2010).

Poderíamos, ainda, pensar em uma abordagem psicossocial com uma verve fortemente humanista, que caminha em direção a uma espécie de autoaceitação e "tolerância" social: "Seria um caminho muito mais saudável se você simplesmente reconhecesse que você é um homem que tem um forte desejo de 'ser' uma mulher, de imitar estereótipos do papel sexual 'feminino' ('gênero') e de buscar 'validação' da sociedade (...)" (PB).

Observa-se que, em ambos os casos, a tentativa de operacionalização de uma racionalidade focada em aspectos psicossociais culmina, frequentemente, em uma manobra nominalista, que universaliza as experiências e demarca o que é socialmente aceitável e o que deve ser erradicado, invertido ou curado. Esse tipo de homogeneização discursiva, como veremos, faz parte da lógica dos manuais médico-psiquiátricos contemporâneos, que, ao estabelecerem categorias estáveis com uma aparente validade científica, influenciam as práticas psicoterápicas, que passam a ter como foco a adaptação social dos supostos pacientes. As formas subjetivas tornam-se, assim, quadros patológicos que, a partir de disposições morais e orientações de conduta, orientam profissionais, sujeitos e todo tecido social em torno de uma norma pré-estabelecida (Dunker; Kyrillos Neto, 2010).

\title{
Psiquiatrização ou cerebralização engajada?
}

O debate sobre a patologização das experiências trans têm dividido a opinião de muitos, inclusive dentro dos próprios movimentos sociais. Nas falas analisadas, a tendência em se manter as transexualidades como quadros psiquiátricos é evidente:

(...) transexualismo causa sofrimento por si mesmo e, portanto, é um transtorno que exige uma nomeação médica e científica adequada para o campo de atuação profissional, e não uma terminologia nociva ou politicamente correta, como pode ser usada nos debates sociais sobre o tema (...) O transexualismo não é uma perversão, não merece estigma, mas é um transtorno (...) (AM).

Essa participante recorreu ao termo "transexualismo" 12 e ao argumento de que a manutenção das experiências trans como um "transtorno psiquiátrico" garantiria o avanço das pesquisas científicas sobre o tema e o acesso dessas pessoas a uma assistência adequada. Observa-se, nesse

\footnotetext{
${ }^{12} \mathrm{O}$ termo deixou de ser adotado a partir do DSM IV, mas ainda é utilizado em discursos e práticas médico-científicos mais conservadoras. Ao mesmo tempo, é um termo totalmente rechaçado pelo movimento LGBT e por produções científicas que problematizam a essencialização das identidades.
} 
caso, que a referência se desloca da concepção de "doença" - ou seja, quadro com uma etiologia (causa) e uma fisiopatologia (alterações fisiológicas patológicas) bem definidas - para a ideia de "transtorno" - tradução consagrada do termo disorder, que, em última instância, se refere a uma disfunção psíquica e social "clinicamente" significativas. Isso reflete a discussão sedimentada no campo psiquiátrico em 1980 com o lançamento do DSM III que culminou no estabelecimento de categorias descritivas objetivas, estáveis, baseadas em estudos empíricos supostamente ateóricos. Uma vez que a psiquiatria desconhece a etiologia e o processo patológico dos quadros que lhe eram endereçados, foi preciso fundar essa nova categoria - "disorder" - que, distanciada de qualquer discussão etiológica, propiciaria uma linguagem comum entre profissionais e pesquisadores, legitimando os seus terrenos de intervenção (Aguiar, 2004).

É, nesse sentido, que a participante advogou que, entender as transexualidades como um "transtorno", permitiria operacionalizar um conhecimento científico universalmente válido e uma abordagem técnica eficaz. Tal pretensão se configurou, de alguma maneira, no próprio corpus empírico que analisamos. O fato de não termos localizado nenhuma fala a respeito das transmasculinidades, por exemplo, além de indicar um entendimento das experiências trans como algo associado exclusivamente ao feminino, nos pareceu reiterar a crença na estabilidade de uma categoria válida para todos, independentemente das especificidades de gênero, sexualidade, idade, raça e classe social.

A mesma participante também alegou que a visão biomédica contribuiria para que esse tipo de vivência não fosse interpretado como uma escolha voluntária, diminuindo a culpabilização e o estigma social dos indivíduos. Para melhor compreender esse ponto, é importante nos questionarmos sobre a pretensão ateórica da noção de "transtorno". Ora, sabemos que a objetividade empírica adotada nessa concepção se aproxima idealmente à objetividade empírica do substrato fisiológico e orgânico. Essa tendência ficou ainda mais clara com o lançamento do DSM $\mathrm{V}$, que definiu categorias com base não só em ensaios estatísticos, mas também em especulações oriundas de pesquisas recentes em genética e neuroimagem. Podemos dizer, assim, que o pretenso "a-teoricismo" nada mais é que a adoção de uma visão fisicalista da perturbação mental (Russo, 2004).

É comum, nesse contexto, o argumento de que aproximar os quadros psiquiátricos das doenças orgânicas contribuiria para diminuição dos preconceitos e do isolamento social experienciados por essas pessoas. Estudos revelam, no entanto, que, apesar dos esforços do discurso científico para conscientizar a sociedade em relação à essa questão, na prática, o que aconteceu foi justamente o contrário. Há, na verdade, uma crescente tendência de se desejar distância de indivíduos com transtornos psiquiátricos como, por exemplo, a esquizofrenia. A ideia de que essa síndrome é uma "doença mental", no sentido biomédico, parece reforçar a concepção de que sujeitos com essas manifestações apresentam uma anormalidade orgânica, permanente e irreversível. Isso os torna "perigosos" e "imprevisíveis", situação que reforça o isolamento social (Watters, 2010).

Quando se trata de experiências trans, o diagnóstico contribui para que essas pessoas não sejam reconhecidas como sujeitos capazes de falar e decidir por si mesmas. A ideia de que esses sujeitos são "transtornados", nesse caso, mina a autonomia para que cada um construa uma narrativa singular de sua identidade e decida pela forma de cuidado que melhor lhe caiba (Borba, 2016).

A pregnância da lógica fisicalista nesse campo se torna ainda mais evidente na fala de uma mulher trans, corroborada por outros participantes:

Eu sou uma paciente que sofre dessa patologia (...) não se trata de construções sociais, de gênero ou de agenda política; trata-se de biologia, como nos sentimos desde que nascemos e como podemos nos consertar para se sentir melhor. (...) é evidente que existem dois sexos diferentes. Pessoas como eu que não concordam com o sexo que lhe fora atribuído quando nasceram não estão se rebelando contra qualquer coisa, mas para adequar o seu corpo sexual ao seu cérebro que determina a qual sexo pertencem (PI). 
O cérebro, nesse contexto, se torna o grande protagonista na definição dos corpos e das formas de subjetivação de cada um. Isso faz parte de uma tendência bastante contemporânea, autorizada por toda uma proliferação de tecnologias, práticas e discursos que borram as fronteiras entre o órgão cerebral e as ideias menos materializáveis relativas ao mental. As identidades passam, assim, a serem determinadas pelo funcionamento neurológico que, em última instância, encarna a "natureza" de cada um (Azize, 2008).

Esse tipo de raciocínio promove uma nova forma de organização social, nomeada por Nikolas Rose (2013) como "cidadania neuroquímica". Ou seja, novos padrões de ativismo biológico em torno de uma compreensão fisicalista dos indivíduos que controla e dociliza os corpos a partir daquilo que o autor chamou de "neuropolítica". Dito de outo modo, apesar de aparentemente estarmos diante de certo engajamento - um verdadeiro "engajamento cerebral" - que abre a possibilidade para que as pessoas empreendam suas autonomias, há um exercício tácito de poder que produz discursos, práticas e saberes com fins de dominação.

Um dos participantes, no entanto, questionou a validade da tese de que o "sexo cerebral" seja o principal determinante da sexualidade humana, citando diversos estudos que comparam os aspectos cerebrais de pessoas trans com pessoas cisgênero:

(...) do ponto de vista da avaliação da qualidade da evidência usando o sistema $\operatorname{GRADE}^{13}$ (...), todas evidências sobre 'sexo cerebral' são inúteis devido aos sérios problemas de imprecisão: amostras muito pequenas, frequentemente obtidas indiretamente (por exemplo, em estudos post mortem) e possivelmente outros tipos de vieses (SP).

É curioso como que os achados desse tipo de estudo são tomados como evidências científicas, mesmo quando se sustentam em metodologias questionáveis. Ao que nos parece, há um na verdade um "pseudocentificismo", que produz afirmações exageradas sem qualquer abertura para refutações e construções de novas perspectivas. Essa é a via que, segundo Hacking (2005), fixa os imperativos do biopoder no contemporâneo. Para ele, o que está em jogo nesse processo é: contar e correlacionar os dados; quantificar; medicalizar; normalizar; biologizar; tornar genético; burocratizar e, finalmente, tomar posse da identidade que assim é fabricada. Aqui, especialmente, estamos no campo do imperativo "biologizemos". Nessa lógica, diversos transtornos mentais mesmo aqueles que se pretende despatologizar, como é o caso das sexualidades - têm sua explicação passando pelo cérebro e por sua neuroquímica, a partir de uma manobra com ares científicos que adquire o efeito de verdade absoluta e imutável.

$\mathrm{E}$, nessa direção, não podemos deixar de lado o papel dos hormônios na construção desse discurso. Como pontua Rohden (2008):

É cada vez mais comum depararmos com artigos em revistas e livros de divulgação científica, ou mesmo em jornais de grande circulação, e com programas de televisão dedicados a tratar da importância dos hormônios no bem-estar e na saúde dos indivíduos e na determinação de certos comportamentos. Quanto mais atual for a matéria, maior será a probabilidade de que trate também da conexão entre cérebro e hormônios e que apresente as diferenças inatas $e$ intransponíveis entre os sexos. A ideia de que os hormônios determinam tudo, até mesmo nossa inteligência e nosso comportamento frente ao sexo oposto, parece ganhar cada vez mais adeptos. Fala-se também em inteligência hormonal. Assistimos ao império de um "corpo hormonal' que parece sobrepor-se a qualquer outra concepção biomédica corrente, pelo menos se considerarmos o sucesso de sua aceitação entre um público cada vez mais amplo (Rohden, 2008:134).

A imutável "natureza do ser" pode, portanto, se valer de um vasto arsenal tecnológico de intervenções no corpo para ser transformada e melhorada, não só no intuito de restaurar uma boa saúde, mas também com o objetivo de aperfeiçoar a performance de cada um. Esse fenômeno é bastante solícito com a lógica de consumo do capitalismo contemporâneo em que o corpo humano se transforma em mercadoria. Uma mercadoria democrática cuja qualidade é regida por valores

\footnotetext{
${ }^{13} \mathrm{O}$ sistema Grading of Recommendations, Assessment, Development and Evaluation (GRADE) tem o objetivo de uniformizar os critérios usados para definir evidências científicas que possam nortear condutas clínicas.
} 
morais que determinam certos ideais do humano ocidental. Há, nesse sentido, a junção entre uma moral subjetiva e uma visão fisicalista focada no funcionamento cerebral, de forma que a segunda acaba englobando a primeira (Azize,2008). Eis uma forma de exercício de poder verificada no "dispositivo da transexualidade" que, finalmente, apaga as singularidades e risca os destinos dos corpos. Diante disso, quais saídas seriam possíveis para operacionalizara diversidade de demandas e desejos que envolvem as experiências trans?

\section{Não-patologização e operacionalização das experiências trans}

De forma geral, a questão central do debate sobre a patologização das experiências trans é que, se por um lado assumir um diagnóstico médico contribui para medicalização de modos de vida não hegemônicos, por outro, a ausência de uma classificação legitimada pelos manuais contemporâneos pode inviabilizar os procedimentos burocráticos dos sistemas de saúde, dificultando (ainda mais) o acesso dessas pessoas às diversas formas de cuidado, incluindo as intervenções corporais para aqueles que as desejam (Bento, 2018).

Conforme observamos, existem variadas estratégias discursivas que sustentam a não patologização dessas experiências:

Sim, há necessidade de ajudar as pessoas transexuais, mas um diagnóstico deve ser baseado em direitos humanos. E isso é aceitar o conhecimento que as pessoas têm sobre seu próprio sexo. Se uma menina sabe que é uma menina, ela deve ser tratada como uma menina pelos médicos. E assim, ser transexual não pode ser uma 'disforia de gênero' ... é uma variação do corpo (RR).

Essa mulher trans parece concordar com a visão psicossociológica de Stoller, que estabeleceu o conceito de "identidade de gênero" para ressaltar que a definição do gênero, ao contrário do que era defendido por Money, dependia mais do sentimento de cada um do que propriamente o comportamento exibido pelo indivíduo (Cyrino, 2013). A autodeterminação de sua própria identidade seria, nesse sentido, a forma mais adequada de conhecer o gênero de cada um. $\mathrm{O}$ ato de falar por si, no entanto, é afetado por diferentes perspectivas: "Eu nasci uma garota com partes do corpo masculinizadas. Por que há tantas pessoas que pensam que têm o direito de falar em nossos nomes?" (RR).

Percebe-se que, nesse caso, a participante, ao mesmo tempo em que legitimou o conhecimento de cada um sobre o seu próprio gênero, reforçou que essa determinação tem, em sua base, algo da organicidade corporal. Independentemente desse paradoxo, ela abre um questionamento importante sobre a questão: se o gênero é exatamente essa sensação individual de pertencimento a certo grupo socialmente estabelecido, como falar em "disforia" ou "incongruência" de gênero? Essa problematização se torna ainda mais premente quando adotamos a ideia de Butler (2002; 2003; 2009) de que o gênero é um exercício performativo continuado que não só reproduz e naturaliza as normas binárias inteligíveis, mas também as desestabiliza, abrindo espaço para novas criações. Ora, na medida em que o gênero se refere a uma performatividade, que envolve não só formas coletivas de estar no mundo, mas também formas singulares de apropriação, termos como "desvio", "disforia", "engano", "incongruência" ou "inadequação" deveriam, de fato, serem proscritos.

$\mathrm{Na}$ prática, no entanto, a repetição estereotipada é privilegiada em detrimento das construções criativas e singulares. É o que frequentemente acontece nos serviços de saúde em que a verdade íntima de cada um acaba sendo ofuscada por um tipo ideal de transexualidade, emergindo-se como uma narrativa hegemônica que deve ser repetida para os profissionais de forma a garantir a autorização institucional e o acesso às intervenções corporais (Borba, 2016).

Mas como garantir o acesso dessas pessoas não por um modelo médico-avaliativo, mas por "um modelo baseado na autonomia e na decisão compartilhada, no qual pessoas trans tenham centralidade decisória e abertura narrativa para intervir no encontro clínico" (Borba, 2016:51)? Em nosso estudo, houve uma única fala que nos pareceu indicar esse caminho:

O nome 'incongruência de gênero' é estigmatizante e impulsionado pelas crenças transfóbicas de que as identidades cisgêneras são melhores que as identidades trans. Questões trans não devem 
ser consideradas doenças. A única razão para mantê-las na CID é a de possibilitar que as pessoas trans realizem modificações no corpo, como tratamento hormonal ou cirurgia. Deveria ser observado que nem todas elas desejam essa transição. Essas modificações alteram o sexo biológico e não têm nada a ver com 'gênero', que é uma construção social. Proponho renomear essa categoria como 'Modificações Corporais Relacionadas à Características Sexuais Secundárias' para manter o foco nas intervenções médicas que as pessoas trans podem ou não desejar, e não em suas identidades ou gênero, que deveriam ser mantidas fora do discurso médico. A categoria proposta (...) deveria ser transferida para a Seção 24, 'Condições Associadas a Intervenções', pois assim se descreverá (...) não a razão do tratamento, mas o tratamento em si (RS).

Talvez, essa alternativa possibilitasse uma coparticipação e corresponsabilização das pessoas trans a partir da "ruptura de um dispositivo que possui como alicerce o impedimento do reconhecimento do outro como sujeito capaz de dizer e decidir por si mesmo" (Teixeira, 2013:285286). Ao que tudo indica, no entanto, essa proposta está longe de ser adotada pelas instituições que determinam as classificações das doenças no contemporâneo, mas se encontra na pauta de militantes, acadêmicos e serviços que apostam na despatologização (Prado, 2018).

\section{Mas, afinal, onde está a incongruência?}

Ao longo deste trabalho, percebemos que as falas sobre as propostas de classificação das experiências trans incidem em um ponto marcado pela "tensão inarredável" entre o romantismo e o iluminismo que caracteriza o universo de valores do mundo ocidental (Duarte, 1994; 2004). Se, por um lado, há alguns discursos mais construcionistas que apontam para centralidade dos sujeitos, de suas vivências e de suas relações na definição das sexualidades e dos gêneros, por outro, há aqueles mais iluministas que se centram na biologia e na fisiologia dos corpos. Independentemente da perspectiva, há sempre um atravessamento de aspectos morais, que nem sempre são evidentes.

$\mathrm{Na}$ prática, ao revermos cada um dos eixos que forjamos ao longo de nossa análise, percebemos que eles se misturam, de forma que seus limites se tornam irregulares e imprecisos (figura 4). Quando discutimos, por exemplo, sobre a ascensão do cérebro sustentada pelo discurso médico-psiquiátrico contemporâneo a respeito das transexualidades é inevitável não recorrer às categorias psicossociológicas para entender, finalmente, como esse órgão assume a materialidade desses elementos movediços de forma a estabilizá-los como uma verdade concreta e inabalável (Duarte, 2018).

Figura 4: Intersecções entre os eixos de análise e de discussão

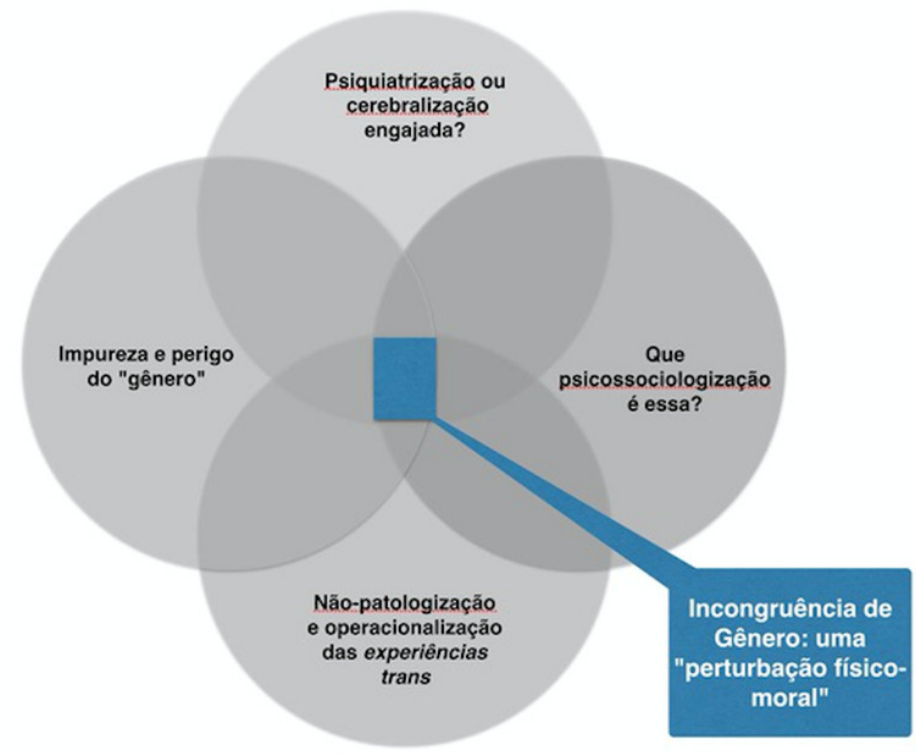

Fonte: Confeccionada pelos autores. 
Essa noção de categorias movediças, não lineares, que contradizem ou confundem as classes ideais, nos remete a discussões pós-estruturalistas a respeito das classificações. De fato, sobretudo quando nos detemos em objetos complexos - como ocorre nas experiências relacionadas às sexualidades e aos gêneros - há sempre um resíduo que resiste a qualquer tentativa de se estabelecer uma delimitação clara entre diferentes categorias. Em nosso estudo, delimitamos a própria concepção de "gênero" como esse "elemento poluente" (Douglas, 1991). Diante disso que escapa, há um esforço permanente de reintegração de certa ordem a partir da noção de que existe uma "natureza" humana independentemente da "cultura". Essa perspectiva é ancorada em um paradigma dualista que, ao sustentar a existência de uma natureza fixa e imutável sobre a qual se desenham incontáveis ditos e não ditos culturalmente determinadas, desconsidera os elementos híbridos que atravessam os próprios domínios da natureza e da cultura que artificialmente estabelecemos (Strathern, 2014). Tais elementos são, em alguma medida, "purificados" a partir de estratégias discursivas que, ao nomeá-los e categorizá-los, criam uma espécie de essência que nos faz tomá-los como objetos concretos ou naturais. É o caso das experiências trans que, ao serem classificadas como "Incongruência de Gênero", mesmo que aparentemente dissociadas dos quadros psiquiátricos a partir da alocação nas "Condições relacionadas à saúde sexual", continuam a ser entendidas como fenômenos psicopatológicos fixos, trans-históricos e universais.

Seguindo esse raciocínio, vale retomar à crítica de Strathern (2014) a respeito das categorias binárias - natureza-cultura, masculino-feminino, selvagem-domesticado etc. — que fazem parte da racionalidade ocidental. A antropóloga, ao estudar as ideias dos povos Hagen, destaca que os elementos impuros, que desafiam as classificações dicotômicas ocidentais apriorísticas, são fundamentais para o estabelecimento da mobilidade da tessitura social. É o caso do gênero que, ao se colocar entre a natureza e a cultura, tensiona a malha social de forma a permitir que as interações e os processos de construção e reconstrução aconteçam. É justamente por isso que Strathern é enfática ao designar o gênero como o "operador da cultura", ou seja, aquilo que faz a sociedade se interagir, se movimentar e se transformar.

No ocidente, esse elemento - assim como todos aqueles que negam a pureza das classes são geridos a partir de uma lógica binária que funciona como uma "ficção persuasiva" bastante potente. Essa elaboração é especialmente válida em nossa investigação, que demonstra, finalmente, que o que é patológico, problemático, disfórico ou incongruente, na verdade, não é o gênero, mas as práticas, os discursos, os ditos e não ditos que tentam, a todo tempo, classificá-lo, purificá-lo, deslegitimá-lo e invisibilizá-lo.

Resgatamos, nesse sentido, a ideia de "perturbação físico-moral" (Duarte, 1998) como ponto de convergência entre nossos eixos de análise (figura 4). O termo "perturbação" se refere a situações que são consideradas "patológicas" em nossa cultura ocidental e "regulares" em outros contextos, evidenciando, assim, que o sofrimento não é intrínseco à condição em si, mas determinado por aspectos sociais, históricos e culturais. O qualitativo "físico-moral", por sua vez, ressalta o "caráter de vínculo ou mediação de que esses fenômenos se cercam nas relações entre a corporalidade e todas as demais dimensões da vida social, inclusive, e eventualmente, a espiritual ou transcendental" (Duarte, 1998:22). Essa perspectiva esclarece que as práticas e os discursos socialmente autorizados que integram o "dispositivo da transexualidade", embora pareçam se sustentar em aspectos objetivos das corporalidades, carregam consigo uma dimensão moral que inclui elementos valorativos sobre certo ideal ocidental. É por essa via que localizamos, na maioria das falas, um consenso velado acerca de pressupostos "naturais" e essencialistas inquestionáveis devido ao efeito "englobante" da visão fisicalista sobre a visão romântica das (trans)sexualidades (Azize,2008). Essa união é essencial para legitimar discursos que passam a ter um estatuto de "verdade científica", apoiando uma lógica binária, heterossexual e patologizante das experiências trans.

Discutir tais questões a partir do corpus investigado é especialmente importante tendo em vista que são os códigos da CID que aparecem nas estatísticas de saúde oficiais do nosso país. Ainda que a retirada da categoria "Incongruência de Gênero" do capítulo dos transtornos mentais tenha significado uma vitória dos movimentos de despatologização, o acesso de pessoas trans aos cuidados em saúde continua problemático. Os novos códigos criados permanecem, em alguma 
medida, patologizando e restringindo o contato dessa população com os serviços de saúde, fomentando inequidades e exclusões.

Nesse processo, conforme destacamos na última fala, a necessidade de um cuidado dos corpos singulares é colocada entre parênteses por um discurso homogêneo que valoriza mais a classificação universal de uma identidade ideal que as intervenções desejadas por cada um. Mas, "como desclassificar e cuidar ao mesmo tempo? Como desclassificar e utilizar da ordem biomédica para cuidar? (Prado, 2018:51).

Nos parece que, para além de qualquer mudança classificatória, é preciso que haja um verdadeiro engajamento ético dos profissionais no sentido de respeitar e reconhecer que as demandas das pessoas trans podem não estar relacionadas a uma tentativa de se atingir a "normalidade", mas de se encontrar um modo melhor de habitar e viver no mundo. Talvez, essa seja a via para que o setting de "tratamento" se desloque do marco patologizante, tornando-se um setting de "cuidado" (Butler, 2011). Ou seja, um local onde ocorra um verdadeiro encontro entre o sujeito e o profissional de forma a comportaras construções singulares e abrir novas possibilidades de laço social.

\section{Referências bibliográficas}

AGUIAR, Adriano Aguiar de. A psiquiatria no divã: entre as ciências da vida e a medicalização da existência. Rio de Janeiro, Relume Dumará, 2004.

ALMEIDA, Guilherme; MURTA, Daniela. Reflexões sobre a possibilidade da despatologização da transexualidade e a necessidade da assistência integral à saúde de transexuais no Brasil. Sexualidad, Salud y Sociedad, Rio de Janeiro, n.14, 2013, pp.380-407.

ARÁN, Márcia; MURTA, Daniela; LIONÇO, Tatiana. Transexualidade e saúde pública no Brasil. Ciência e Saúde Coletiva, Rio de Janeiro, v.14, n. 4, 2009, pp.1141-1149.

ÁVILA, Simone. Transmasculinidades a emergência de novas identidades políticas e sociais. Rio de Janeiro, Editora Multifoco, 2014.

AZIZE, Rogério Lopes. Uma neuro-weltanschauung? Fisicalismo e subjetividade na divulgação de doenças e medicamentos do cérebro. Mana, v.14, n. 1, 2008, pp.7-30.

BENJAMIN, Harry. The transsexual phenomenon. New York, The Julian Press, 1966.

BENTO, Berenice. O que é transexualidade. São Paulo, Brasiliense, 2008.

The review process of the DSM 5: cisgender a cultural or diagnostic category? Sociology International Journal, v.2, 2018, pp.205-213.

BENTO, Berenice; PELÚCIO, Larissa. Despatologização do gênero: a politização das identidades abjetas. Estudos Feministas, Florianópolis, v.20, n. 2, 2012, pp.569-581.

BORBA, Rodrigo. $O$ (des)Aprendizado de si: transexualidade, interação e cuidado em saúde. Rio de Janeiro, Editora FIOCRUZ, 2016.

BUTLER, Judith. Prólogo: transexualidade, transformaciones. In: MISSÉ, Miquel; COLL-PLANAS, Gerard. (ed.) El género desordenado: críticas em torno a la patologización de la transexualidade. BarcelonaMadrid, Egales, 2011, pp.9-13.

Desdiagnosticando o gênero. Physis, Rio de Janeiro, v.19, n. 1, 2009, pp.95-126.

. UndoingGender. New York; London, Routledge, 2004.

. Problemas de gênero: feminismo e subversão da identidade. Rio de Janeiro, Civilização Brasileira, 2003. 2002.

Cuerpos que importan: sobre los límites materiales y discursivos del "sexo". Buenos Aires, Paidós,

CYRINO, Rafaela. A produção discursiva e normativa em torno do transexualismo: do verdadeiro sexo ao verdadeiro gênero. Crítica e Sociedade, Uberlândia, v.3, n. 1, 2013, pp.92-98. 
De SANTANA, Ediane Lopes. As mulheres contra o patriarcado e as relações desiguais de gênero: aspectos teóricos e práticos no combate às opressões. Universidade e Sociedade, Brasilia, ano XXVI, n. 58, 2016, pp.32-40.

DOUGLAS, Mary. Pureza e perigo: ensaio sobre as noções de poluição e tabu. Lisboa, Edições 70, 1991.

DUARTE, Luiz Fernando Dias. Ciências humanas e neurociências: um confronto crítico a partir de um contexto educacional. Revista Brasileira de Ciências Sociais, v.33, n. 97, 2018, pp.1-20.

A sexualidade nas ciências sociais: leitura crítica das convenções. In: PISCITELLI, Adriana; GREGORI, Maria Filomena; CARRARA, Sérgio. Sexualidade e saberes. convenções e fronteiras. Rio de Janeiro, Garamond, 2004, pp.39-80.

O império dos sentidos: sensibilidade, sensualidade e sexualidade. In: HEILBORN, Maria Luiza(org.). Sexualidade: o olhar das Ciências Sociais. Rio de Janeiro, Zahar, 1999, pp.21-30.

Investigação Antropológica sobre Doença, Sofrimento e Perturbação: uma Introdução. In: DUARTE, Luiz Fernando Dias; LEAL, Ondina Fachel (org.). Doença, sofrimento, perturbação: perspectivas etnográficas. Rio de Janeiro, Editora FIOCRUZ, 1998, pp.9-27.

A outra saúde mental, psicossocial ou físico moral? In: ALVES, Paulo César; MINAYO, Maria Cecília Souza(org.). Saúde e doença: um olhar antropológico. Rio de Janeiro, Editora FIOCRUZ, 1994. pp.83-90.

DUNKER, Christian Ingo Lenz; KYRILLOS NETO, Fuad. Curar a Homossexualidade?: a psicopatologia prática do DSM no Brasil. Rev. Mal-Estar Subj., Fortaleza, v.10, n. 2, 2010, pp.425-446.

DURKHEIM, Émile; MAUSS, Marcel. Algumas formas primitivas de classificação. Contribuição para o estudo das representações coletivas. In: MAUSS, Marcel. Ensaios de Sociologia. São Paulo: Perspectiva, 1981 [1903], pp.399-455.

FOUCAULT, Michel. Microfísica do poder. Rio de Janeiro, Graal, 2011.

História da sexualidade 1: a vontade de saber. Rio de Janeiro, Editora Graal, 2009.

A arqueologia do saber. Rio de Janeiro, Forense Universitária, 2008. 1999a.

Em Defesa da sociedade: curso no Collège de France (1975-1976). São Paulo, Martins Fontes,

.A ordem do discurso: aula inaugural no Collège de France, pronunciada em 2 de dezembro de 1970. São Paulo, Edições Loyola, 1999b.

HACKING, Ian. Façonnerlesgens II. In:___. Philosophie et histoire des concepts scientifiques (Resumo de curso). Paris, Collège de France, 2005 [http://www.college-defrance.fr/media/historique/UPL5879_Hacking2004_2005.pdf - acesso em 05 set 2016].

LEITE JR, Jorge. Nossos corpos também mudam: a invenção das categorias "travesti" e "transexual" no discurso científico. São Paulo, Annablume, 2011.

LIONÇO, Tatiana. Atenção integral à saúde e diversidade sexual no Processo Transexualizador do SUS: avanços, impasses e desafios. Physis, Rio de Janeiro, v.19, n. 1, 2009, pp.43-63.

MISKOLCI, Richard. Exorcizando um fantasma: os interesses por trás do combate à "ideologia de gênero". cadernos pagu (53), Campinas, SP, Núcleo de Estudos de Gênero-Pagu/Unicamp, 2018, pp.1-14.

PACHECO, Bárbara Guimarães Costa; RASERA, Emerson Fernando; PRADO, Marco Aurélio Máximo; TEIXEIRA, Flávia do Bonsucesso. Psicologias e transexualidades: escritas e escrituras da psicologia social brasileira. In: RASERA, Emerson Fernando; PEREIRA, Maristela de Souza; GALINDO, Dolores (org.). Democracia participativa, estado e laicidade: psicologia social e enfrentamentos em tempos de exceção. Porto Alegre, ABRAPSO, 2017, pp.204-221.

PRADO, Marco Aurélio Máximo. Ambulare. Belo Horizonte, PPGCOM-UFMG, 2018.

ROHDEN, Fabíola. O império dos hormônios e a construção da diferença entre os sexos. Hist. cienc. saúdeManguinhos, Rio de Janeiro, v.15, 2008, pp.133-152.

ROSE, Nikolas. A política da própria vida: biomedicina, poder e subjetividade no século XXI. São Paulo, Paulus, 2013. 
RUSSO, Jane Araújo. From psychic to somatic: notes on the reframing of the contemporary self. Hist. cienc. saúde-Manguinhos, Rio de Janeiro, v.24, supl.1, 2017, pp.157-169.

Do desvio ao transtorno: a medicalização da sexualidade na nosografia psiquiátrica contemporânea. In: PISCITELLI, Adriana; GREGORI, Maria Filomena; CARRARA, Sérgio (org.). Sexualidade e saberes. convenções e fronteiras. Rio de Janeiro, Garamond, 2004, pp.95-109.

SANTOS, Maria de Fátima Lima. A invenção do dispositivo da transexualidade: produção de "verdades" e experiências trans. Em Pauta, Rio de Janeiro, v.9, n. 28, 2011, pp.117-130.

SOUZA, Érica Renata de; BRAZ, Camilo. Políticas de saúde para homens trans no Brasil: contribuições antropológicas para um debate necessário. In: VAL, Alexandre Costa; DIAS, Fernando Machado Vilhena; GOMES, Gabriela de Lima. Multiplicando os gêneros nas práticas em saúde. Ouro Preto, Editora da UFOP, 2016, pp.149-172.

STRATHERN, Marilyn. Sem natureza, sem cultura: o caso Hagen. In: STRATHERN, Marilyn. $O$ efeito etnográfico e outros ensaios. São Paulo, Cosac Naify, 2014, pp.23-75.

TEIXEIRA, Flávia do Bonsucesso. Dispositivos de dor. saberes-poderes que conformam as transexualidades. São Paulo, Annablume, 2013.

WATTERS, Ethan. A americanização da doença mental. Rev. latinoam. psicopatol. fundam., São Paulo, v.13, n. 1, 2010, pp.102-115.

VELHO, Gilberto. Individualismo e cultura: notas para uma antropologia da sociedade contemporânea. Rio de Janeiro, Zahar, 2008. 